\title{
In vitro Multiple Shoot Regeneration from Petunia hybrida
}

\author{
Rebaz Rasul Habas, ${ }^{1, a}$, Musa Turker ${ }^{2, b, *}$, Fethi Ahmet Ozdemir ${ }^{3, c}$ \\ ${ }^{I}$ Department of Molecular Biology and Genetics, Institute of Natural and Applied Science, Van Yüzüncü Yll Universtiy, 65080 Van, Turkey \\ ${ }^{2}$ Department of Bioengineering, Faculty of Chemical and Metallurgical Engineering, Ylldiz Technical University, 34210 Istanbul, Turkey. \\ ${ }^{3}$ Department of Molecular Biology and Genetics, Faculty of Science and Art, Bingol University, 12000 Bingol, Turkey. \\ *Corresponding author
}

\begin{tabular}{|c|c|}
\hline A R T I C L E I N F O & A B S T R A C T \\
\hline $\begin{array}{l}\text { Keywords: } \\
\text { Petunia hybrida } \\
\text { In vitro } \\
\text { Multiple shoot } \\
\text { Regeneration } \\
\text { Gibberellic acid }\end{array}$ & $\begin{array}{l}\text { An efficient plant regeneration protocol was developed from in vitro germinated seeds of Petunia } \\
\text { hybrida an ornamentally important plant in the family Solanaceae. Shoot tip and node explants of } \\
\text { Petunia hybrida were cultured on MS basal medium supplemented with different concentrations and } \\
\text { combinations of Benzyl amino purine (BAP), 1-Naphthaleneacetic acid (NAA), Indole-3-butyric } \\
\text { acid (IBA) and Gibberellic acid }\left(\mathrm{GA}_{3}\right) \text {. The highest shoot length was obtained from MS medium } \\
\text { supplemented with } 1 \mathrm{mg} / \mathrm{l} \mathrm{BAP}+1 \mathrm{mg} / \mathrm{NAA} \text {. The highest shoot number }(3 \text { shoots/explant) were } \\
\text { obtained from MS medium supplemented with } 0.6 \mathrm{mg} / \mathrm{BAP}+0.5 \mathrm{mg} / \mathrm{IBA} \text {. The isolated shoots } \\
\text { were transferred to MS basal medium supplemented with different concentrations of GA } 3 \text { ranging } \\
\text { from } 0.05,0.2,0.5 \text { and } 1 \mathrm{mg} / 1 \text { for shoot elongation. The highest shoot length }(5.75 \mathrm{~cm}) \text { was recorded } \\
\text { from the MS medium supplemented with } 0.2 \mathrm{mg} / 1 \mathrm{GA} 3+0.2 \mathrm{mg} / 1 \mathrm{BAP} \text {. Rooting of regenerated } \\
\text { shoots were achieved on MS medium supplemented with } 0.1-1 \mathrm{mg} / 1 \mathrm{IBA} \text { and NAA. The regenerated } \\
\text { shoots with well developed roots were successfully acclimatized and established in pots containing } \\
\text { sterilized peat moss and grown under laboratory conditions with } 70 \% \text { survival rates. }\end{array}$ \\
\hline
\end{tabular}

\section{Introduction}

Ornamental plants are grown for decorative purposes in gardens and landscape design projects, as house plants, for cut flowers and specimen display. The cultivation of the plants is called floriculture, forming a major branch of horticulture. Petunia hybrida having colourful flowers and a long florescence shows high ornamental value and now is widely cultivated throughout the world (Quattrochio et al., 1999). It has become an important ornamental model crop in floriculture of high commercial interest (Sink, 1984). Petunias are grown in gardens for their large, showy multicoloured flowers and it is also an important cut flower crop. Breeding of petunias began nearly 30 years after the plant's discovery. Many species other than P. atkinsiana are also gaining popularity in the home garden. A wide range of flower colours, sizes, and plant architectures are available in both $P$. atkinsiana and other species. Petunia genus is consisted of 35 species of flowering plants origination from America. The plant is closely related to tobacco, cape gooseberries, tomatoes, deadly nightshades, potatoes, and chili peppers in the same family of Solanaceae. The popular flower of the same name derived its epithet from the French, which took the word petun, meaning "tobacco," from a Tupi-Guarani language. An annual, most of the varieties seen in gardens are hybrids $(P$. $\times$ atkinsiana, also known as $P . \times$ hybrida). Petunia, which is believed to be the first cultivated bedding plant, is now the most preferred flower crop of the modem bedding plant industry. Petunias can be found in every colour of the rainbow in solids, contrasting waves or hedges and star patterns. The flowers may be large or small, ruffled, fringed or double. They bloom from spring until frost. Many petunias, especially white and lavender cultivars have a very sweet fragrance (Sabitha et al., 2009).

Because of economical and ornamental importance of the plant, it is necessary to produce in vitro. Up to date no more studies available in the literature to regenerate the plant in controlled laboratory conditions. Therefore an efficient and permanent in vitro regeneration protocol is necessary for the plant. Regenerating ornamental plant in the field or in vivo directly causes some problems, such as disease and environmental affect, labour cost and large area of earth etc. Ornamental plants can be regenerated by 
tissue culture approach. Because, plant tissue culture is a collection of techniques used to maintain or grow plant cells, tissues or organs under sterile conditions on a nutrient culture medium of the known composition. Plant tissue culture is widely used to produce clones of a plant in a method known as micropropagation.

A moderate rate of multiplication of petunia through tissue culture has been reported earlier through direct organogenesis from shoot apices (Sharma and Mitra, 1976) and through indirect organogenesis from leaf bits and stem segments (Rao et al., 1973) and shoot tips (Dash and Singhsamant, 1990). The effect of different levels of naphthaleneacetic acid (NAA) and benzyl adenine (BA) on shoot multiplication and regeneration of Petunia hybrida was studied. Seeds of Petunia hybrida were germinated in vitro on MS basal medium. The seedlings were used as a source of explants for the multiplication and regeneration experiments (Abu-Qaoud et al., 2010). Growth regulators induce the competence of tissue to respond to further developmental signals. Li et al., (2013) improved two optimal media for in vitro culture of microspores and germination of mature pollen in Petunia hybrida. The effect of different levels of naphthalene acetic acid (NAA) and benzyl adenine (BA) on shoot multiplication and regeneration of Petunia hybrida was studied. Seeds of Petunia hybrida were germinated in vitro on MS basal medium (Abu-Qaoud et al., 2010). The effect of different levels of naphthalene acetic acid (NAA) and benzyl adenine (BA) on shoot multiplication and regeneration of Petunia hybrida was studied. The regenerated adventitious shoots were cultured on MS medium without growth regulator. These shoots were then rooted (Abu-Qaoud et al., 2010).

Up to date little is known on in vitro regeneration of the plant which is an ornamentally and medicinally important plant. A new and different protocol was developed in the present study.

\section{Materials and Methods}

The seeds were purchased from Istanbul Tohumculuk (Turkey) company. To establish healthy petunia cultures, different concentrations of $\mathrm{NaOCl}$ in time of durations (4, 6,8 and $10 \%$ for 5, 10 minutes) were used for seeds surface sterilization. As a result the best concentration and duration was determined. After sterilization, the seeds were thoroughly rinsed several times with sterile distilled water before being inoculated in the culture medium to remove the traces of the chemicals. Plant culture medium was prepared from commercially available premixed powders. Murashige and Skoog (MS), Gamborg's B5 and White (Wt) media (Duchefa) were initially used for the germination, growth and development.

The ready made media were supplemented with $30 \mathrm{gl} / 1$ sucrose as an energy source and $6 \mathrm{~g} / \mathrm{l}$ agar as a gelling agent (Duchefa). Then the $\mathrm{pH}$ was adjusted to $5.7 \pm 0.1$ with $1 \mathrm{~N}$ $\mathrm{NaOH}$ or $\mathrm{HCl}$. The whole components were dissolved on hot plate magnetic stirrer and the medium was dispensed into culture flasks at a rate of $25 \mathrm{ml}$ and caped with polyethylene or aluminum foils and autoclaved at $121^{\circ} \mathrm{C}$ and $1.5 \mathrm{~atm}$ for $20 \mathrm{~min}$. Two explants were cultured on each culture vessel. Shoot tip were cut aseptically approximately in $1 \mathrm{~cm}$ and lateral buds in $1 \mathrm{~cm}$ long then initiated on MS medium supplemented with 3 levels of 6Benzyl aminopurine (BAP) $(0.3,0.5,1 \mathrm{mg} / \mathrm{l})$ with 2 levels of NAA $(0.5,1 \mathrm{mg} / \mathrm{l})$ and 2 levels of IBA (Indole-butyric acid) $(0.5,1 \mathrm{mg} / \mathrm{l})$ for shoot induction.

After four weeks of culture, developed shoots in the petri dish were sub cultured and long explants were inoculated in culture jars $(5 \times 10 \mathrm{~cm})$ in MS basal medium supplemented with different concentration and combination of BAP and GA3. Plant shoots were maintained for 3 weeks in elongation medium. In vitro raised shoots in $2 \mathrm{~cm}$ and above were excised from the culture tube or culture bottle and sub cultured into MS medium containing different concentration of IBA and NAA for root induction. $0.2,1 \mathrm{mg} / \mathrm{l} \mathrm{NAA}$ and $0.2,1 \mathrm{mg} / \mathrm{l}$ IBA and $1 \mathrm{mg} / \mathrm{l}$ NAA were added separately to MS medium and kept 4 weeks to obtain roots. After four weeks, acclimatized plants were transferred to the pots containing normal garden soil and maintain in greenhouse under normal day length conditions.

\section{Percentage Calculation}

The percentage given in the tables was calculated as follows. The number of incubated explants from which the data is provided was multiplied by 100 and the result was divided by the total number of explants. The results related to mean of provided data were obtained by taking arithmetical average in the rest.

\section{Results}

The highest regeneration percentage of P.hybrida seeds were recorded at $90 \%$ when they were treated with $8 \%$ of $\mathrm{NaOCl}$ for 5 minutes as compared with the other treatments (Table 1 and 2).

Table 1 Effect of different $\mathrm{NaOCl}$ concentration for 5 minutes on the survival percentage of seeds.

\begin{tabular}{c|cc}
\hline $\begin{array}{c}\mathrm{NaOCl} \\
(\%)\end{array}$ & $\begin{array}{c}\text { Seed germination } \\
(\%)\end{array}$ & $\begin{array}{c}\text { Contamination } \\
(\%)\end{array}$ \\
\hline 4 & 0 & 100 \\
6 & 92 & 50 \\
8 & 90 & 0 \\
10 & 20 & 0 \\
\hline
\end{tabular}

Significantly higher seed germination was also recorded at $75 \%$ when seeds were treated with $8 \%$ of $\mathrm{NaOCl}$ for 10 minutes as compared with the rest. The seeds were applied to $10 \%$ of $\mathrm{NaOCl}$ and rinsed three times with double distilled water for sterilization. However, the survival rate of seeds were recorded to be 0.0 . None of the seeds were germinated because of the high concentration of $\mathrm{NaOCl}$. The seeds were cultured on three different type of media MS, B5 and Wt.

Table 2 Effect of different $\mathrm{NaOCl}$ concentration for 10 minutes on the survival percentage of seeds.

\begin{tabular}{c|cc}
\hline $\mathrm{NaOCl}$ & $\begin{array}{c}\text { Seed germination } \\
(\%)\end{array}$ & $\begin{array}{c}\text { Contamination } \\
(\%)\end{array}$ \\
\hline 4 & 10 & 80 \\
6 & 85 & 30 \\
8 & 75 & 0 \\
10 & 0 & 0 \\
\hline
\end{tabular}


Multiple shoots were directly induced when shoot tips cultured on MS medium supplemented with different concentration of BAP, NAA and IBA. The highest length of shoots was $(2.25 \mathrm{~cm})$ recorded in $\mathrm{MS}$ medium supplement with $1 \mathrm{mg} / \mathrm{l} \mathrm{BAP}+1 \mathrm{mg} / \mathrm{l} \mathrm{NAA}$, but the lowest length was recorded $(0.25 \mathrm{~cm})$ in $\mathrm{MS}$ medium supplemented with $0.3 \mathrm{mg} / \mathrm{l}$ BAP $+0.5 \mathrm{mg} / \mathrm{l} \mathrm{IBA}$. The highest number of shoots ( 3 shoots/explant) were obtained from MS medium supplemented with $0.6 \mathrm{mg} / \mathrm{l} \mathrm{BAP}+0.5$ $\mathrm{mg} / \mathrm{l} \mathrm{IBA}$, but the least numbers of shoots were recorded (1 shoots/explant) in MS medium supplement with $1 \mathrm{mg} / \mathrm{l}$ $\mathrm{BAP}+0.5 \mathrm{mg} / \mathrm{l} \mathrm{NAA}, 0.6 \mathrm{mg} / \mathrm{l} \mathrm{BAP}+0.1 \mathrm{mg} / \mathrm{l} \mathrm{IBA}$ and $0.3 \mathrm{mg} / \mathrm{l} \mathrm{BAP}+0.1 \mathrm{mg} / \mathrm{l} \mathrm{IBA}$. The highest number of leaves (15 leaves/explant) was achieved in MS medium supplemented with $1 \mathrm{mg} / \mathrm{l} \mathrm{BAP}+1 \mathrm{mg} / \mathrm{l} \mathrm{NAA}$. The lowest number of leaves were obtained from (3 leaves/ explant) MS medium supplement with $0.6 \mathrm{mg} / \mathrm{l} \mathrm{BAP}+0.5 \mathrm{mg} / \mathrm{l}$ NAA and $0.6 \mathrm{mg} / \mathrm{l} \mathrm{BAP}+0.5 \mathrm{mg} / \mathrm{l}$ IBA (Table 3 ).

The maximum number of roots were recorded (15 roots/explant) in MS medium supplement with $0.3 \mathrm{mg} / \mathrm{l} \mathrm{BAP}$ $+0.1 \mathrm{mg} / \mathrm{l}$ IBA. The maximum length of roots was recorded in MS medium supplement with $1 \mathrm{mg} / \mathrm{l} \mathrm{BAP}+1 \mathrm{mg} / \mathrm{l} \mathrm{NAA}$ is $(4.67 \mathrm{~cm})$ but the minimum length of roots $(0.4 \mathrm{~cm})$ was determined in MS medium supplement with $0.3 \mathrm{mg} / \mathrm{l} \mathrm{BAP} \mathrm{+}$ $0.1 \mathrm{mg} / \mathrm{l} \mathrm{IBA}$. Multiple shoot growth was observed directly from nodal explants on MS medium fortified with different concentrations $(0.3,0.6$ and $1 \mathrm{mg} / \mathrm{l})$ of BAP combined with different concentration $(0.5$ and $1 \mathrm{mg} / \mathrm{l})$ of oxins NAA and IBA. The highest length of shoots was produced on node explant $(1.5 \mathrm{~cm})$ incubated in MS medium supplemented with $0.3 \mathrm{mg} / \mathrm{l} \mathrm{BAP}+0.5 \mathrm{mg} / \mathrm{l} \mathrm{NAA}$ while the lowest length of shoots was $(0 \mathrm{~cm})$ in MS medium supplement with $0.3 \mathrm{mg} / \mathrm{l}$ $\mathrm{BAP}+0.5 \mathrm{mg} / \mathrm{l} \mathrm{IBA}$. Maximum number of shoots were observed in MS medium supplemented with $1 \mathrm{mg} / \mathrm{l} \mathrm{BAP}+1$ mg/l NAA (4 shoots/ explant). But the minimum number of shoots was detected in the medium supplemented with 0.3 mg/l BAP + 0.5 mg/l IBA (Table 3).
The highest number of leaves (13.5 leaves/explant) were recorded from nodal explants cultured on MS medium supplemented with $1 \mathrm{mg} / \mathrm{l} \mathrm{BAP}+1 \mathrm{mg} / \mathrm{l} \mathrm{NAA}$. But the lowest number of leaves (0 leaves/explant) were recorded from node explants in MS medium supplemented with $0.3 \mathrm{mg} / \mathrm{l} \mathrm{BAP}+0.5 \mathrm{mg} / \mathrm{l} \mathrm{IBA}$. The maximum number of roots (6.5 roots/explants) was obtained from MS medium supplemented with $0.6 \mathrm{mg} / \mathrm{l} \mathrm{BAP}+0.5 \mathrm{mg} / \mathrm{l} \mathrm{IBA}$. The minimum number of roots (0 roots/explant) was detected in MS medium supplemented with $0.3 \mathrm{mg} / \mathrm{L}$ BAP $+0.5 \mathrm{mg} / \mathrm{l} \mathrm{NAA}, 0.6 \mathrm{mg} / \mathrm{l} \mathrm{BAP}+1 \mathrm{mg} / \mathrm{l} \mathrm{NAA}, 1 \mathrm{mg} / \mathrm{l} \mathrm{BAP}$ $+1 \mathrm{mg} / \mathrm{l} \mathrm{NAA}, 1 \mathrm{mg} / \mathrm{l} \mathrm{BAP}+0.5 \mathrm{mg} / \mathrm{lBA}$ and $0.3 \mathrm{mg} / \mathrm{l}$ $\mathrm{BAP}+0.5 \mathrm{mg} / \mathrm{l} \mathrm{IBA}$.

The best result of root length $(3.50 \mathrm{~cm})$ was recorded when the shoots were transferred to medium containing 0.6 $\mathrm{mg} / \mathrm{l}$ BAP +0.1 mg/l IBA. Unfortunately, no root development was $(0 \mathrm{~cm})$ recorded from nodal incubated in MS medium supplemented with $0.3 \mathrm{mg} / \mathrm{l} \mathrm{BAP}+0.5 \mathrm{mg} / \mathrm{l}$ NAA , $0.6 \mathrm{mg} / \mathrm{l} \mathrm{BAP}+1 \mathrm{mg} / \mathrm{l} \mathrm{NAA}, 1 \mathrm{mg} / \mathrm{l} \mathrm{BAP}+1 \mathrm{mg} / \mathrm{l}$ $\mathrm{NAA}, 0.6 \mathrm{mg} / \mathrm{l} \mathrm{BAP}+0.5 \mathrm{mg} / \mathrm{l} \mathrm{NAA}, 1 \mathrm{mg} / \mathrm{l} \mathrm{BAP}+0.5$ $\mathrm{mg} / \mathrm{l} \mathrm{IBA}$ and $0.3 \mathrm{mg} / \mathrm{l} \mathrm{BAP}+0.5 \mathrm{mg} / \mathrm{lBA}$.

The data in Table 4 explain the effect of different BAP and NAA concentration on shoot and root length and number of shoots, leaves and root per explant. The longest shoot was recorded in MS medium supplemented with 1 $\mathrm{mg} / \mathrm{l} \mathrm{BAP}+1 \mathrm{mg} / \mathrm{l} \mathrm{NAA}(2.25 \mathrm{~cm})$. The highest number of shoots was obtained (3 shoots/explant) from shoots tip cultured in MS medium supplemented with $0.6 \mathrm{mg} / \mathrm{l} \mathrm{BAP}$ $+0.5 \mathrm{mg} / \mathrm{l}$ NAA. The highest number of leaves per explant was recorded from shoot tip explants in MS medium supplemented with $0.3 \mathrm{mg} / \mathrm{l} \mathrm{BAP}+0.5 \mathrm{mg} / \mathrm{l} \mathrm{NAA}(10.5$ leaves/explant). The highest number of roots (12 roots/explant) was obtained from shoot tips cultured in MS medium supplemented with $0.3 \mathrm{mg} / \mathrm{l} \mathrm{BAP}+0.5 \mathrm{mg} / \mathrm{l}$ NAA. The longest roots $(4.6 \mathrm{~cm})$ from shoot tip explants were recorded in MS medium supplemented with $1 \mathrm{mg} / \mathrm{l}$ $\mathrm{BAP}+1 \mathrm{mg} / \mathrm{l} \mathrm{NAA}$.

Table 3 Effect of BAP with NAA, IBA on shoot tip and node explants of Petunia hybrida.

\begin{tabular}{|c|c|c|c|c|c|c|c|c|c|}
\hline PGRs & $\mathrm{C}$ & & & $E$ & $\mathrm{SL} / \mathrm{E}$ & $\mathrm{NS} / \mathrm{E}$ & NL/E & $\mathrm{R} / \mathrm{E}$ & $\mathrm{RL} / \mathrm{E}$ \\
\hline \multirow{2}{*}{ BAP } & \multirow{2}{*}{$0.3+$} & & \multirow{2}{*}{0.5} & Shoot tip & 1.5 & 2.5 & 10.67 & 12.33 & 3.00 \\
\hline & & & & Node & 1.5 & 2.5 & 11.00 & 0.00 & 0.00 \\
\hline \multirow{2}{*}{ BAP } & \multirow{2}{*}{$0.6+$} & \multirow{2}{*}{ NAA } & \multirow{2}{*}{1} & Shoot tip & 1.5 & 2 & 8.50 & 6.50 & 3.00 \\
\hline & & & & Node & 0.2 & 2 & 1.50 & 0.00 & 0.00 \\
\hline \multirow{2}{*}{ BAP } & \multirow{2}{*}{$0.3+$} & \multirow{2}{*}{ NAA } & \multirow{2}{*}{1} & Shoot tip & 0.7 & 2 & 5.50 & 2.50 & 1.60 \\
\hline & & & & Node & 0.5 & 2.5 & 6.50 & 2.50 & 0.60 \\
\hline \multirow{2}{*}{ BAP } & \multirow{2}{*}{$1+$} & \multirow{2}{*}{ NAA } & \multirow{2}{*}{0.5} & Shoot tip & 0.3 & 1 & 4.50 & 4.00 & 1.75 \\
\hline & & & & Node & 0.4 & 2.5 & 7.50 & 0.50 & 0.15 \\
\hline \multirow{2}{*}{ BAP } & \multirow{2}{*}{$1+$} & \multirow{2}{*}{ NAA } & \multirow{2}{*}{1} & Shoot tip & 2.25 & 2.5 & 15.00 & 10.50 & 4.67 \\
\hline & & & & Node & 1.15 & 4 & 13.50 & 0.00 & 0.00 \\
\hline \multirow{2}{*}{ BAP } & \multirow{2}{*}{$0.6+$} & \multirow{2}{*}{ NAA } & \multirow{2}{*}{0.5} & Shoot tip & 0.5 & 2.5 & 3.00 & 3.50 & 0.60 \\
\hline & & & & Node & 0.25 & 3.5 & 2.50 & 5.50 & 0.00 \\
\hline \multirow[b]{2}{*}{ BAP } & \multirow{2}{*}{$1+$} & \multirow[b]{2}{*}{ IBA } & \multirow{2}{*}{0.1} & Shoot tip & 0.7 & 1.5 & 6.00 & 6.00 & 2.50 \\
\hline & & & & Node & 0.5 & 2 & 4.50 & 6.00 & 1.25 \\
\hline \multirow{2}{*}{ BAP } & \multirow{2}{*}{$1+$} & \multirow{2}{*}{ IBA } & \multirow{2}{*}{0.5} & Shoot tip & 0.6 & 2.5 & 6.00 & 6.00 & 0.45 \\
\hline & & & & Node & 0.3 & 2 & 4.00 & 0.00 & 0.00 \\
\hline \multirow{2}{*}{ BAP } & & & & Shoot tip & 0.75 & 1 & 5.00 & 9.50 & 2.50 \\
\hline & $0.0+$ & IBA & 0.1 & Node & 0.8 & 2 & 4.00 & 4.50 & 3.50 \\
\hline & & & & Shoot tip & 0.3 & 3 & 3.00 & 4.50 & 0.55 \\
\hline BAP & $0.6+$ & IBA & 0.5 & Node & 0.2 & 0 & 2.50 & 6.50 & 0.25 \\
\hline & 03 & & & Shoot tip & 0.25 & 2 & 3.50 & 3.00 & 0.75 \\
\hline ВАР & $0.3+$ & IBA & 0.5 & Node & 0 & 0 & 0.00 & 0.00 & 0.00 \\
\hline & & & & Shoot tip & 0.7 & 1 & 3.50 & 15.00 & 0.40 \\
\hline ВАР & $0.3+$ & IBA & 0.1 & Node & 0.1 & 1 & 1.00 & 1.00 & 0.20 \\
\hline
\end{tabular}

C: Concentration (mg/l), E: Explant, SL/E: Shoot Length $(\mathrm{cm}) /$ Explant, NS/E: No of Shoot/explant, NL/E: No of Leaves/explant, R/E: No. of Roots/explant, RL/E: Root Length (cm)/explant 
Table 4 Effect of BA and NAA on shoot multiplication from shoot tip explants.

\begin{tabular}{l|ccccc}
\hline PGR concentration $(\mathrm{mg} / \mathrm{l})$ & Shoot length $(\mathrm{cm})$ & Shoot No & Leaf number & Root No & Root length (cm) \\
\hline 0.3 BAP+0. 5 NAA & 1.5 & 2.5 & 10.5 & 12 & 3 \\
0.3 BAP + NAA & 0.7 & 2 & 5.5 & 2.5 & 1.6 \\
0.6 BAP +0.5 NAA & 0.5 & 3 & 3 & 3.5 & 0.6 \\
0.6 BAP + 1 NAA & 1.5 & 2 & 8.5 & 6.5 & 3 \\
1 BAP +0.5 NAA & 0.3 & 1 & 4.5 & 4 & 1.7 \\
1 BAP + 1 NAA & 2.25 & 2.5 & 15 & 10.5 & 4.6 \\
\hline
\end{tabular}

Table 5 Effect of BA and NAA on shoot multiplication stage from axillary node explants.

\begin{tabular}{l|ccccc}
\hline PGR concentration $(\mathrm{mg} / \mathrm{l})$ & Shoot length $(\mathrm{cm})$ & Shoot No & Leaf number & Root No & Root length $(\mathrm{cm})$ \\
\hline 0.3 BAP+0. 5 NAA & 1.5 & 2.5 & 11 & 0 & 0 \\
0.3 BAP + NAA & 0.5 & 2.5 & 6.5 & 2.5 & 0.6 \\
0.6 BAP + 0.5 NAA & 0.25 & 3.5 & 2.5 & 5.5 & 0.35 \\
0.6 BAP + 1 NAA & 0.2 & 2 & 1.5 & 0 & 0 \\
1 BAP +0.5 NAA & 0.4 & 2.5 & 7.5 & 0.5 & 0.15 \\
1 BAP + 1 NAA & 1.15 & 4 & 13.5 & 0 & 0 \\
\hline
\end{tabular}

Table 6 Effect of BA and IBA on shoot multiplication stage from shoot tip explants

\begin{tabular}{l|cccrr}
\hline PGR concentration $(\mathrm{mg} / \mathrm{l})$ & Shoot length $(\mathrm{cm})$ & Shoot No & Leaf number & Root No & Root length $(\mathrm{cm})$ \\
\hline 1 BAP +0.1 IBA & 0.7 & 1.5 & 6 & 6 & 2.5 \\
1 BAP +0.5 IBA & 0.6 & 2.5 & 6 & 6 & 0.45 \\
0.6 BAP +0.1 IBA & 0.75 & 1 & 5 & 9.5 & 2.6 \\
0.6 BAP +0.5 IBA & 0.3 & 3 & 3 & 4.5 & 0.55 \\
0.3 BAP +0.1 IBA & 0.7 & 1 & 3.5 & 3 & 0.4 \\
0.3 BAP +0.5 IBA & 0.25 & 2 & 3.5 & 15 & 0.75 \\
\hline
\end{tabular}

Table 5. showed that different BAP and NAA concentration in MS medium was significantly effective on the number of shoots per explant and the number of leaves and shoot length and number of roots and root length produced on the shoot from the culture of axillary node explant. The highest number of leaves (13.5 Leaves /explant) was achieved in MS medium supplemented with $1 \mathrm{mg} / \mathrm{l} \mathrm{BAP}+1 \mathrm{mg} / \mathrm{l}$ NAA. The highest number of adventitious shoot regeneration (4 shoots/explant) was produced from axillary node explant in MS medium supplemented with $1 \mathrm{mg} / \mathrm{l} \mathrm{BAP}+1 \mathrm{mg} / \mathrm{l} \mathrm{NAA}$. The highest length of shoots was observed in MS medium supplement with $0.3 \mathrm{mg} / \mathrm{l} \mathrm{BAP}+0.5 \mathrm{mg} / \mathrm{l} \mathrm{NAA}(1.5 \mathrm{~cm})$. The highest number of roots was produced in MS medium supplemented with $0.6 \mathrm{mg} / \mathrm{l} \mathrm{BAP}+0.5 \mathrm{mg} / \mathrm{l} \mathrm{NAA}$. The highest length of roots was recorded $(0.6 \mathrm{~cm})$ on the shoot tip explant cultured in MS medium supplemented with 0.3 $\mathrm{mg} / \mathrm{l} \mathrm{BAP}+1 \mathrm{mg} / \mathrm{l} \mathrm{NAA}$. The other treatments did not produce roots but they produced callus.

Table 6 shows the effect of BAP on shoot regeneration of Petunia shoot tip explants and the effect of IBA on rooting of Petunia's microshoots. The addition of $0.6 \mathrm{mg} / 1$ $\mathrm{BAP}+0.1 \mathrm{mg} / \mathrm{l} \mathrm{IBA}$ in MS medium was the best concentration on shoot formation, $(0.75 \mathrm{~cm})$ per shoot. The highest number of shoot formation ( 3 shoots/explant) was recorded from culture in MS medium supplemented with $0.6 \mathrm{mg} / \mathrm{l} \mathrm{BAP}+0.5 \mathrm{mg} / \mathrm{l} \mathrm{IBA}$. The highest number of leaves (6 leaves/shoot) were provided from $1 \mathrm{mg} / \mathrm{BAP}+$ $0.1 \mathrm{mg} / \mathrm{l} \mathrm{IBA}$ and $1 \mathrm{mg} / \mathrm{l} \mathrm{BAP}+0.5 \mathrm{mg} / \mathrm{l} \mathrm{IBA}$ supported MS medium. The highest root number was recorded by the addition of $0.3 \mathrm{mg} / 1 \mathrm{BAP}+0.5 \mathrm{mg} / \mathrm{l} \mathrm{IBA}$. In that culture medium 15 roots/explant were produced. The longest root $(2.6 \mathrm{~cm})$ was recorded in the MS medium supplement with $0.6 \mathrm{mg} / \mathrm{l} \mathrm{BAP}+0.1 \mathrm{mg} / \mathrm{l} \mathrm{IBA}$.
Table 7 declares the effect of different BAP and IBA concentration on shoot development. The highest shoot length was measured $(0.8 \mathrm{~cm})$ in MS medium supplement with $0.6 \mathrm{mg} / \mathrm{l} \mathrm{BAP}+0.1 \mathrm{mg} / \mathrm{l} \mathrm{IBA}$. In ddition, $\mathrm{MS}$ medium supplemented witth $0.6 \mathrm{mg} / \mathrm{l} \mathrm{BAP}+0.5 \mathrm{mg} / \mathrm{l}$ caused the highest shoot number (4.5 shoot/explant). In axillary node explant the highest number of leaves formation was produced in MS medium supplement with $1 \mathrm{mg} / \mathrm{l} \mathrm{BAP} \mathrm{+}$ $0.1 \mathrm{mg} / \mathrm{l} \mathrm{IBA}$. The highest number of root was recorded in MS medium supplemented with $0.6 \mathrm{mg} / \mathrm{l} \mathrm{BAP}+0.5 \mathrm{mg} / \mathrm{l}$ IBA (6.5 roots/ explant). The highest length of roots was produced in MS medium supplement with $0.6 \mathrm{mg} / \mathrm{BAP}+$ $0.1 \mathrm{mg} / 1(3.5 \mathrm{~cm} / \mathrm{shoot})$.

Table 8 shows the effect of gibberellin on shoot length of Petunia. The highest length of shoots was recorded from the MS medium supplemented with $0.2 \mathrm{mg} / \mathrm{l} \mathrm{GA} 3+0.2$ $\mathrm{mg} / \mathrm{l}$ BAP $(5.75 \mathrm{~cm})$. The highest number of leaves $(23$ leaves/shoot) was achieved when GA3 was added at 0.2 $\mathrm{mg} / \mathrm{l}$ concentration in MS medium. The addition of $\mathrm{GA}_{3}$ at $0.2 \mathrm{mg} / \mathrm{l}$ concentration gave the best result on axillary node formation (23 node/shoots). The highest internode length formation was produced in MS medium supplement with $0.2 \mathrm{mg} / \mathrm{l} \mathrm{GA} \mathrm{G}_{3}+0.2 \mathrm{mg} / \mathrm{l} \mathrm{BAP}(0.85 \mathrm{~cm})$. But the lowest result was taken from $\mathrm{MS}$ medium supplemented with $0.05 \mathrm{mg} / \mathrm{l} \mathrm{GA}_{3}+0.5 \mathrm{mg} / \mathrm{BAP}(0.1 \mathrm{~cm})$.

The results showed that different concentration of IBA and NAA in MS medium had significant effect on root length per explant and the number of roots per explant after four weeks of culturing for rooting of the plant. Table 9 shows the effect of IBA on root formation of Petunia's shoots. The highest number of roots was recorded in MS medium supplemented with $1 \mathrm{mg} / \mathrm{IBA}$ (6.8 roots/shoot), subsequently $0.8 \mathrm{mg} / \mathrm{l} \mathrm{IBA}$ ( 5 roots $/ \mathrm{shoot})$. The highest root length $(3.2 \mathrm{~cm})$ was achieved in MS medium supplemented with $1 \mathrm{mg} / \mathrm{l} \mathrm{IBA}$ an $0.8 \mathrm{mg} / \mathrm{l} \mathrm{IBA}(3 \mathrm{~cm})$ respectively. 
Table 7 Effect of BA and IBA on shoot multiplication stage from axillary node explants.

\begin{tabular}{l|cccrr}
\hline PGR concentration $(\mathrm{mg} / \mathrm{l})$ & Shoot length $(\mathrm{cm})$ & Shoot No & Leaf number & Root No & Root length (cm) \\
\hline 1 BAP +0.1 IBA & 0.5 & 2 & 4.5 & 6 & 1.25 \\
1 BAP +0.5 IBA & 0.3 & 2 & 4 & 0 & 0 \\
0.6 BAP +0.1 IBA & 0.8 & 2 & 4 & 4.5 & 3.5 \\
0.6 BAP +0.5 IBA & 0.2 & 4.5 & 2.5 & 6.5 & 0.25 \\
0.3 BAP +0.1 IBA & 0.1 & 1 & 1 & 1 & 0.2 \\
0.3 BAP +0.5 IBA & 0 & 0 & 0 & 0 & 0 \\
\hline
\end{tabular}

Table 8 Effect of $\mathrm{GA}_{3}$ on shoot length stage.

\begin{tabular}{l|cccc}
\hline PGR concentration $(\mathrm{mg} / \mathrm{l})$ & Shoot length $(\mathrm{cm})$ & Leaf number & Axillary Node & Internode length $(\mathrm{cm})$ \\
\hline $0.2 \mathrm{GA}_{3}+0.2 \mathrm{BAP}$ & 5.75 & 12 & 10 & 0.85 \\
$0.2 \mathrm{GA}_{3}+0.5 \mathrm{BAP}$ & 5.25 & 16 & 14 & 0.55 \\
$0.05 \mathrm{GA}_{3}+0.5 \mathrm{BAP}$ & 2.2 & 10 & 10 & 0.1 \\
$0.05 \mathrm{GA}_{3}+0.2 \mathrm{BAP}$ & 3 & 13 & 10 & 0.2 \\
$0.2 \mathrm{GA}_{3}$ & 4.5 & 23 & 23 & 0.3 \\
$0.5 \mathrm{GA}_{3}$ & 1.5 & 7 & 7 & 0.2 \\
$1 \mathrm{GA}_{3}$ & 4.5 & 10 & 9 & 0.5 \\
\hline
\end{tabular}

Table 9 Effect of IBA on rooting formation.

\begin{tabular}{c|cc}
\hline Concentration of $(\mathrm{mg} / \mathrm{l})$ & No of Root/shoot & Root length $(\mathrm{cm})$ \\
\hline 0.1 & 0.2 & 0.5 \\
0.3 & 1.2 & 1.2 \\
0.5 & 2.5 & 2 \\
0.8 & 5 & 3 \\
1 & 6.8 & 3.2 \\
\hline
\end{tabular}

When the regenerated plantlets reached to $5-6 \mathrm{~cm}$ in length $4-5 \mathrm{~cm}$ in root, they were removed from the culture medium and wash thoroughly in running tap water. Plantlets were transferred to plastic pots containing sterile filled with perlite and peat. (3:1). Plantlets were kept in a chamber with 80-90\% relative humidity under a 16/8 h (light/dark) of photoperiod. Potted plantlets were to cover with transparent plastic bags to ensure high humidity and watered every three days for two weeks. Plants were acclimatized in ambient condition and survived in $70 \%$.

\section{Discussion}

The application of tissue culture techniques on petunia started in the late 1960's (Binding, 1971). The main objective of this work was to study influence to different conditions on morphogenesis and organogenesis of the plant. The present study includes the works in which the role of explants and plant growth regulators on the regeneration of Petunia was investigated. The role of certain plant growth regulators as major factors of in vitro morphogenetic processes is reflected in this study. We described the development of explants and their differentiation to whole plants. The primary goal is to clone certain Petunia line in vitro for horticultural uses.

Shoot tip and axillary node were found to be most regenerative explants on the micropropagation of Petunia hybrida. Seeds were sterilized in four different concentration of sodium hypo chloride $(\mathrm{NaOCl})(4,6,8$ and $10 \%$ ), at two different time of period (5 and $10 \mathrm{~min}$.). The best and contamination free germination (at 90\%) was obtained from the application of 10 minutes and $8 \%$ of $\mathrm{NaOCl}$ concentration. In 10 minutes and $10 \%$ of $\mathrm{NaOCl}$ application resulted in germination at $20 \%$. The main reason for the result could be the size of the seeds. The thin layer surface of small seeds was probably injured and caused to death due to high concentration and time of application period of $\mathrm{NaOCl}$. Lower $\mathrm{NaOCl}$ application (4\%) caused contamination due to insufficient sterilization and no germination was observed. Moreover, different results were obtained when different application period and concentration of $\mathrm{NaOCl}$ were used (Hailu et al., 2015; Walla et al., 2016).

In the current study, three types of plant media without PGR were applied for the germination of Petunia hybrida's seeds. The best results for seed germination was obtained from MS medium with $90 \%$, which was more than the germination ratio in B5 medium and White medium resulted in $70 \%$ and $50 \%$ germination respectively. The reason could be due to the chemical structures, vitamins, macro elements and microelements concentration in each media which were different from each other. The yellowish colour change was observed in seedlings. It was thought that the reason could be Fe deficiency. $0.005 \mathrm{mg} / \mathrm{l} \mathrm{Fe}$ was added in MS medium and the colour of the plant was turned to original green.

Walla et al., (2016) demonstrated that the clonal propagation of plants from explants is a rapid emergence of organs which can ultimately give rise to plant. The multiplication stage was repeated at regular intervals to produce large-scale shoot for commercially use. The shoot induction and proliferation are mostly depended on plant growth regulators and types of explants. The exogenous Cytokinin, BAP can steer the shoot tip and nodal segment explants to produce shoots in vitro. To understand the action of cytokinin, it is required that the actual concentration of the compound within the incubation medium should be characterized during the developmental process (Fosket, 1980; Van der Krieken et al., 1990). 
Explants and endogenous PGRs concentration are important factors for the success of in vitro plant regeneration. Moreover, meristematic cell containing explants can increase shoot multiplication. In the other hand, regenerated shoots from axillary buds and shoot tips are true types because in their regeneration process (Kharrazi et al., 2011). In the present study, combination of cytokinin and auxin was found to be more productive on shoot organogenesis. The combination of BAP with IBA and NAA was resulted in adventitious shoot, leaaf and root formation. Parallel results were reported by Annapurna and Rathore, (2010).

The major effects of BAP and other cytokinin's have been characterized in a limited plant tissues and their activities differ significantly (Laloue, 1977). The benzyl adenine (BA) glucosides are normally considered to be inactive. The BA ribosides (BAR) and free base may be involved in the regulation of cell division or other developmental processes (Letham and Palni, 1983). Shoot tip explant was applied to BAP and in combination with NAA and IBA in MS medium to increase shoot growth. The highest shoot length was provided to be $2.25 \mathrm{~cm}$ in MS medium supplement with $1 \mathrm{mg} / \mathrm{l} \mathrm{BAP}+1 \mathrm{mg} / \mathrm{l} \mathrm{NAA}$. The increased concentration of BAP caused increasing shoot production. Vidya et al., (2013) and Mahadev et al., (2014) reported that the combination of auxin and cytokinin supports the differentiation of organogenesis

The highest number of shoots (3 shoots/explant) was recorded in MS medium supplement with $0.6 \mathrm{mg} / \mathrm{BAP}+$ $0.5 \mathrm{mg} / \mathrm{l}$ NAA. Parallel results were reported by Sharmin et al., (2008). Axillary node explant was applied to BAP in combination with NAA in MS medium to increase multiple shoot regeneration MS medium supplement with $1 \mathrm{mg} / \mathrm{l}$ $\mathrm{BAP}+1 \mathrm{mg} / \mathrm{l} \mathrm{NAA}$ gave the maximum number of shoots (4 shoots/explant) and the shoot length $(1.15 \mathrm{~cm})$. The synergistic effect of cytokinin and low auxin for multiple shoot induction has been reported in the same family Solanaceae (Khadiga et al., 2009).

Effect of different concentration of cytokine, BAP and auxins, NAA and IBA on direct shoot regeneration was investigated. The maximum number of shoot induction in shoot tip explants was observed on MS medium supplemented with $0.6 \mathrm{mg} / \mathrm{l} \mathrm{BAP}+0.5 \mathrm{mg} / \mathrm{l} \mathrm{IBA} \mathrm{(3}$ shoots/explant). The highest length of shoots was produced on node explant $(0.8 \mathrm{~cm})$ incubated in MS medium supplemented with $0.6 \mathrm{mg} / \mathrm{l} \mathrm{BAP}+0.1 \mathrm{mg} / \mathrm{l} \mathrm{IBA}$. The results show the higher potential of the collective effect of BAP, NAA for shoot induction than those of BAP, IBA. The growth of the above ground part was particularly strongly stimulated by 0.2 and $0.05 \mathrm{mg} / \mathrm{l}$ of gibberellic acid $\left(\mathrm{GA}_{3}\right)$ in combination with BAP. Plantlets were developed in MS medium supplemented with $0.2 \mathrm{mg} / \mathrm{l} \mathrm{GA}_{3}+0.2 \mathrm{mg} / \mathrm{l}$ BAP $(5.75 \mathrm{~cm}$ in lenght). Plants regenerated on MS medium supplement with $0.2 \mathrm{GA}_{3}$ gave the highest number of leaves (23) which is in agreement with the results by Kulpa and Nowak, (2011). Gibberellins are recognized to have a stimulatory effect on shoot elongation in many species, aside from helping in the further growth and development of preformed organs. This can be ascribed to the increased transport of potassium ions assisted by gibberellin (Kulpa and Nowak, 2011).

The function of rooting stage is to prepare plantlets for transplanting and acclimatization to outside environment
(Hartmann and Kester, 1983). Auxins have several promoting roles in tissue culture and they have the facility to promote root initiation (Wetherell, 1982). Synthetic auxins such as IBA and NAA are frequently used for in vitro root initiation and increasing root number and length even present alone or in combination.

Regenerated shoots of Petunia hybrida was established from the previous stage with the length of 1.5 to $4 \mathrm{~cm}$ and the plants were rooted in MS medium supplement with different concentrations and combinations of IBA and NAA. Our data showed that MS medium supplemented with $1 \mathrm{mg} / \mathrm{l} \mathrm{IBA}+0.2$ NAA gave the highest number of root formation per explant (9 roots/explant) and also the best root length of root per explant (4 roots/explant) obtained from the similar media after four weeks. MS medium supplemented with $0.1 \mathrm{mg} / \mathrm{l} \mathrm{NAA}$ and also 0.1 IBA showed a very few root formation. In our research IBA was more effective than NAA with respect to rooting of the regenerated shoots. The same result has been reported by Husain et al., (1999).

These results in agreements with Otroshy et al., (2011). The MS medium supplemented with $1 \mathrm{mg} / \mathrm{l}$ NAA was effective for inducing root formation on Capsicum plants and also IBA was more effective for root induction than NAA even alone or in combination with each other. In the present study, regeneration of Petunia hybrida was greatly achieved by using different plant growth regulators supplemented with MS medium. It was concluded that MS medium supplemented with $1 \mathrm{mg} / \mathrm{l} \mathrm{BAP}+1 \mathrm{mg} / \mathrm{l}$ NAA was proven to be the best medium for primary establishment of direct organogenesis of Petunia hybrida in all the treatments based on available shoot tip and nodal explants. The best result for shoot elongation was recorded in MS medium supplemented with $0.2 \mathrm{mg} / \mathrm{l} \mathrm{GA}_{3}$. Plantlets grown under these conditions gave higher number of leaves and auxiliary nodes. Auxins such as NAA and IBA added to MS medium in concentration with $1 \mathrm{mg} / \mathrm{lBA}+0.2 \mathrm{mg} / \mathrm{l}$ NAA was appeared to be the most useful for rooting of Petunia hybrida. Petunia plant rooted in this way was recorded to have numerous roots.

A high survival acclimatization of the in vitro grown plantlets was proven the validity of the development into healthy plants after being transferred to chamber. The present study describes an efficient protocol for in vitro regeneration of Petunia hybrida. For future perspective, the protocol can be applied for large scale production of the plant for commercial purpose and the regenerated plant may be used for medicinal purpose.

\section{References}

Abu-Qaoud H, Abu-Rayya A, Yaish S. 2010. In vitro regeneration and somaclonal variation of Petunia hybrida. Journal of Fruit and Ornamental Plant Research, 18(1): 7181.

Annapurna D, Rathore TS. 2010. Direct adventitious shoot induction and plant regeneration of Embelia ribes Burm F. Plant Cell, Tissue and Organ Culture (PCTOC), 101(3): 269277.

Binding H. 1971. Organogenese and kallus von Petunia hybrida. Zeitschrift fur Pflanzenphysiologie, 359-364.

Dash SN, Singhsamant PK. 1990. Induction of plantlets and callus from shoot-tips of Petunia hybrida cultured in vitro. Orissa Journal of Horticulture, 18(1-2): 65-69. 
Fosket DE. 1980. Hormonal control of morphogenesis in cultured tissues. In Plant Growth Substances 1979, Springer Berlin Heidelberg, 362-369.

Hailu T, Abera B, Daksa J. 2015. In Vitro direct organogenesis protocol for mass propagation of an elite Ethiopian hot pepper (Capsicum annuum L.) cultivar mareko fana. American Journal of Plant Sciences, 6(9): 1435.

Hartmann HT, Kester DF. 1983. Plant propagation principles and practices. 4 Ed. Prentice Hall, IWC. England, New Jersey, pp: 276.

Husain S, Jain A, Kothari SL. 1999. Phenylacetic acid improves bud elongation and in vitro plant regeneration efficiency in Capsicum annuum L. Plant Cell Reports, 19(1): 64-68.

Khadiga G, Rasheid SM, Mutasim M K. 2009. Effect of Cultivar and Growth Regulator on In vitro Micropropagation of Potato (Solanum tuberosum L). American-Eurasian Journal of Sustainable Agriculture, 3(3): 487-492.

Kharrazi IVM, Nemati H, Tehranifar A, Bagheri A, Sharifi A 2011. Culture of Carnation (Dianthus caryophyllus L.) Focusing on the Problem of Vitrification. Journal of Biological and Environmental Sciences, 5(13): 9-26.

Kulpa D, Nowak N. 2011. In vitro flowering of Petunia $\times$ atkinsiana D. Don. Folia Horticulturae, 23(2): 125-129.

Laloue M. 1977. Cytokinins: 7-glucosylation is not a prerequisite of the expression of their biological activity. Planta, 134(3): 273-275.

Letham DS, Palni LMS. 1983. The biosynthesis and metabolism of cytokinins. Annual Review of Plant Physiology, 34(1): 163-197.

Li F, Li C, Li M, Yu M, Fang, C, Wang S. 2013. In vitro culture of Petunia hybrida microspores and Agrobacterium-mediated transient expression of $\beta$-glucuronidase (GUS) reporter gene. Int. J. Agric. Biol, 15: 1098-1104.

Mahadev MD, Panathula CS, Naidu CV. 2014. Efficient protocol for direct shoot organogenesis from in vitro raised nodal explants of Solanum viarum (Dunal)-An important anticancer medicinal plant. International Journal of Medicinal and Aromatic Plants, 4(1): 48-55.

Murashige T, Skoog F. 1962. Revised medium for rapid growth and bioassay with tobacco micro-propagated. Physiologia Plantarum, 15: 473-9.
Otroshy M, Moradi K, Khayam Nekouei M. 2011. The effect of different cytokenins in propagation of capsicum annuиm $\mathrm{L}$. by in vitro nodal cutting. Trakia Journal of Sciences, 9(3): 2130.

Quattrocchio F, Wing J, Van der Woude K, Souer E, De Vetten N, Mol J, Koes R. 1999. Molecular analysis of the anthocyanin 2 gene of petunia and its role in the evolution of flower color. The Plant Cell, 11(8): 1433-1444.

Rao PS, Handro W, Harada H. 1973. Bud formation and embryo differentiation in in vitro cultures of Petunia. Zeitschrift für Pflanzenphysiologie, 69(1): 87-90.

Sabitha C, Jawaharlal M, Ganga M, 2009. Direct organogenesis in petunia (Petunia hybrida Vilm.). Journal of Ornamental Horticulture, 12(1): 15-21.

Sharma AK, Mitra GC. 1976. In vitro culture of shoot apical meristem of Petunia hybrida for mass production of plants. Indian journal of experimental biology, 348-350.

Sharmin S A, Kabir A H, Mandal A, Sarker K K, Alam M F. 2008. In vitro propagation of eggplant through meristem culture. Agriculturae Conspectus Scientificus (ACS), 73(3): 149-155.

Sink K C. 1984. Taxonomy. In Petunia. Springer Berlin Heidelberg: (pp. 3-9)

Van der Krieken W M, Croes A F, Smulders MJ, Wullems GJ. 1990. Cytokinins and flower bud formation in Vitro in Tobacco role of the metabolites. Plant physiology, 92(3): 565-569.

Vidya SM, Krishna V, Manjunatha B K, Pradeepa M R. 2013. Micropropagation of Clerodendrum serratum L. through direct and indirect organogenesis. Plant Tissue Culture and Biotechnology, 22(2): 179-185.

Walla M, Elmaksood A, Fawzia A E, Hussein A B. 2016. In vitro Propagation of the Endangered Medicinal Plant Hyoscyamus muticus L. (Egyptian Henbane). J. Appl. Environ. Biol. Sci. 6(4): 25-34.

Wetherell DF. 1982. Introduction to in vitro propagation. Avery Pub Group. 